\title{
ODPOVĚDNÉ VEŘEJNÉ ZADÁVÁNÍ
}

\section{RESPONSIBLE PUBLIC PROCUREMENT}

\author{
Kateřina Burešová \\ Západočeská univerzita v Plzni, Fakulta právnická
}

https://doi.org/10.33542/SIC2019-2-03

\begin{abstract}
ABSTRAKT
$V$ minulosti se veřejné zadáváni stalo nástrojem politiky státu, jehož prostřednictvím se realizovala podpora určitých odvětví, výrobků nebo skupin podnikatelu. Taková pomoc často směrovala do vybraných lokalit. Trendem současného veřejného zadávání je rovněž podpora, která však není namírena př́mo. Podporuje se skupina obyvatel, výrobky nebo služby. Nejsou nikterak spojeny s konkrétními dodavateli nebo lokalitou, ale zohledñuji se jejich aspekty považované za podpory vhodné. U lidí je to např́klad uplatnění na trhu práce, zapojení do pracovního procesu apod. U výrobků a služeb pak vlastnosti, způsob výroby, použité materiály, životní cyklus atp.
\end{abstract}

\begin{abstract}
In the past, public procurement has become a government policy tool through which support has been given to certain sectors, products or groups of entrepreneurs. Such support often directed to selected regions. The current public procurement trend is also supportive, but not directly targeted. A group of people, products or services are supported. They are in no way associated with specific suppliers or regions, but their aspects considered appropriate are taken into account. For example, people who might be employed in the labor market, who are involved in the work process, and so on. In the case of products and services, the quality, the method of production, the materials used, the life cycle, and so on.
\end{abstract}

\section{I. ÚVOD}

Veřejné zadávání je tradičně spjato s vysokou mírou formalismu. Naplno se projevil v souvislosti s harmonizací pravidel veřejného zadávání v rámci Evropské unie. Typicky toto období nastartoval přelom 80. a 90. let minulého století, kdy vznikala první generace zadávacích směrnic. Jejich smyslem bylo zavedení jednotné vnitřní politiky voblasti veřejného zadávání, která by účinně vytvářela jednotný vnitřní trh bez bariér. Ty totiž značně jednotlivé zakázkové trhy $\mathrm{v}$ členských státech diferencovaly a co více, omezovaly účast zahraničních soutěžitelů. Praktický dopad původní, nulté generace zadávacích směrnic ${ }^{1}$, byl $\mathrm{v}$ tomto ohledu nevýznamný.

Směrnice Rady 71/305 EHS ze dne 26. července 1971 o koordinaci postupů zadávání veřejných zakázek na stavební práce a směrnice Rady 77/62/EHS ze dne 21. prosince 1976 o koordinaci postupů zadávání veřejných zakázek na dodávky. 
Nabubřelá byrokracie znesnadňovala efektivní zadávání veřejných zakázek a obor po přijetí první generace zadávacích směrnic ${ }^{2}$ trpěl. Roztříštěná a nejednoznačná pravidla vedla k nové koncepci veřejného zadávání. Ta se zrcadlila až v následující generaci směrnic, kdy již jediný předpis sjednotil pravidla pro zadávání zakázek na dodávky, služby a stavební práce. ${ }^{3}$ Pro překonání některých nedostatků předchozích směrnic ještě došlo ke změně uveřejňovacích povinností a ke vzniku společného slovníku pro veřejné zakázky. ${ }^{4}$ Nadto nová směrnice zavedla nové druhy zadávacích řízení a upřesnila výkladové nejasnosti z předchozích směrnic. Přesto administrativně bylo zadávací řízení stále plné formalismů a prostor pro flexibilní odklon od pevných pravidel minimální.

V roce 2014 vychází směrnice Evropského parlamentu a Rady 2014/24/EU ze dne 26. února 2014 o zadávání veřejných zakázek a o zrušení směrnice 2004/18/ES, jejíž transpozice byla provedena zákonem č. 134/2016 Sb., o zadávání veřejných zakázek (dále také jako „ZZVZ“). Dnes již snad lze konstatovat, že podle současných pravidel zadávání veřejných zakázek, lze v relativně krátkém čase pořídit požadované plnění, přičemž lze dokonce stanovovat pravidla pro jednotlivá zadávací ř́zení natolik efektivně, že se rozvíjí v souvislosti s veřejným zadáváním i odpovědnostní politika státu.

\section{ODPOVĚDNÉ ZADÁVÁNÍ}

Smysl odpovědného zadávání spočívá v aktivní politice státu směřující k plnění závazků ve vztahu k odpovědnosti sociální, environmentální a dalších oblastech, kde se stát zavázal $\mathrm{k}$ jejich podpoře a prohlubování. V souvislosti s odpovědností, kterou to které zadávací ř́zení implementuje, můžeme hovořit o zeleném veřejném zadávání (green public procurement), sociálně odpovědném veřejné zadávání (social responsible public procurement), veřejném zadávání odpovědném k životnímu prostředí (enviromentally responsible public procurement) a podobně. Podstatou není název, pod kterým odpovědné zadávání najdeme, ale jeho faktický obsah. Kličem je pak plnění primárních a druhotných cílů. Primárním cílem je pořízení plnění požadovaného zadavatelem. Požadavek je determinován potřebou zadavatele. Druhotným cílem je podpora vybrané klíčové oblasti, která se jednoduše provádí stanovením odpovídajících podmínek pro plnění nebo nároků kladených na dodavatele, procesy výroby atp. Samozřejmě lze kombinovat obojí a možnosti rozvoje odpovědného zadávání jsou velmi široké a mají potenciál se rozrůstat.

Jednotlivé segmenty odpovědného zadávání sledují samostatné cíle. Odpovědné veřejné zadávání lze označit za „proces, při kterém zadavatel nakupuje produkty, služby a stavební práce, které potřebuje, přičemž získává maximální hodnotu za peníze vytvářením prospěchu pro společnost, ekonomiku, a minimalizací negativních dopadů na životní prostředí. “5

Z hlediska životního prostř̌edí je základem zohledňování dopadů na životní prostředí. Typicky se projeví při pořizování zboží a služeb, kdy se sleduje výroba, použité materiály nebo náklady životního cyklu. Neméně relevantní je ukazatel životnosti, jehož prostřednictvím lze splnit několik kritérií současně. Jednak úspora finanční, kdy se snižují náklady na obnovu plnění (pořízení plnění nového). Dále nízké náklady na údržbu během životnosti. Při likvidaci se ukazuje hledisko ekologické, nebot' ta nemusí vyžadovat zvláštní způsob nakládání, když neobsahuje nebezpečné nebo neekologické součásti. Zadavatel

2 Směrnice 93/36/EHS o koordinaci postupů při zadávání veřejných zakázek na dodávky, 93/37/EHS o koordinaci postupů při zadávání veřejných zakázek na stavební práce a 92/50 o koordinaci postupů při zadávání veřejných zakázek na služby. Směrnice č. 2004/18/ES o koordinaci postupů při zadávání veřejných zakázek na stavební práce, dodávky a služby.

4 Nař́zení Evropského parlamentu a Rady (ES) č. 2195/2002 ze dne 5. listopadu 2002 o společném slovníku pro veřejné zakázky (CPV).

5 NOVÁK, David, Leona GERGELOVÁ ŠTEIGROVÁ, Monika DOBROVODSKÁ, et al. Odpovědné veřejné zadávání: metodika. Praha: Ministerstvo práce a sociálních věcí ČR, 2017. ISBN 978-80-7421-134-8. str. 6. 
stanoví podmínky tak, že připouští pouze plnění zabezpečující ochranu životního prostředí, nízké nároky na využití vyčerpatelných přírodních zdrojů nebo omezení použití některých neekologických surovin. ${ }^{6}$

Obdoba zadávání veřejných zakázek zohledňující ochranu životního prostředí s rovnocenným efektem se ukrývá i pod označením „zelené veřejné zadávání“77 nebo také „enviromentally responsible public procurement ${ }^{\star 8}$ nebo ve Spojených státech amerických se vžil termín „enviromentally preferable purchasing ${ }^{\text {“9 }}$. Zelené veřejné zadávání představuje výzvu pro zadavatele, aby v souvislosti s požadovaným plněním zohledňovali v soutěži zboží a služby šetrné k životnímu prostředí. ${ }^{10}$ Komise Evropské unie vyzvala zadavatele, aby přijali vlastní odpovědnost a ujali se role v procesu zavedení zeleného managementu a jeho úlohy $\mathrm{v}$ upřednostňování produktů $\mathrm{s}$ šetrným dopadem na životní prostředí. ${ }^{11}$ Zavedla koncept tzv. IPP (Integrated Product Policy ${ }^{12}$ ), jehož hlavní myšlenkou je zohlednění životního cyklu plnění pořízeného zadavatelem. V současné zadávací směrnici je právě na životní cyklus kladen značný důraz. V zákoně o zadávání veřejných zakázek se to projevuje např́klad tak, že ekonomická výhodnost nabídek zosobňuje zohledňování různých aspektů nabízeného plnění nad ekonomické hledisko jediného kritéria, kterým je cena. Ekonomická výhodnost zohledňující náklady životního cyklu se hodnotí na základě nejvýhodnějšího poměru nabídkové ceny a kvality včetně poměru nákladů životního cyklu a kvality. ${ }^{13}$ Ve stejném duchu je koncipován zákon č. 343/2015 Z.z., o verejnom obstarávaní, kde v ustanovení $\S 44$ odst. 3 nabízí zadavateli možnost hodnotit nabídky podle nejlepšího poměru ceny a kvality, nákladů životního cyklu a na posledním místě ceny. Ochrana životního prostředí, tedy environmentální zadávání, může ve veřejném zadávání zohledňovat určité způsoby výroby, které jsou šetrné k životnímu prostředí, upřednostňují delší životní cyklus na úkor vyšší pořizovací ceny, výrobky nenáročné na likvidaci (nebezpečného) odpadu, výrobky bez vnějších průvodních škodlivých vlivư ${ }^{14}$ a další.

$\mathrm{Na}$ společenskou roli zadavatele a sociální kritéria výběru nejvhodnější nabídky se soustředí společensky odpovědné veřejné zadávání (Socially Responsible Public Procurement). Může se uplatnit v podpoře zaměstnávání některých skupin obyvatelstva, vzdělávání, integrace menšin, pracovních práv nebo fair trade.

V souvislosti s odpovědným veřejným zadáváním se setkáváme s udržitelným veřejným zadáváním (Sustainable Public Procurement). Udržitelné zadávání implikuje dva základní aspekty, sociální a environmentální. Z hlediska sledovaných zájmů, jež tvoří nástroje politiky státu, je udržitelné zadávání vlastně relevantním hlediskem naplňování určených cílů veřejného zadávání, jakož i vlastní politiky státu.

Udržitelné zadávání představuje proces, v němž organizace (tj. zadavatel) uspokojuje své potřeby pořizováním zboží, služeb a stavebních prací takovým způsobem, který naplňuje princip získání nejvýhodnější hodnoty v rámci životního cyklu, který současně neposkytuje

6 LI, Lin a Ken GEISER. Environmentally responsible public procurement (ERPP) and its implications for integrated product policy (IPP). Journal of Cleaner Production. 2005, 7(13), 10. ISSN 0959-6526.

7 Jedná se o koncepci odpovědného zadávání v Organizaci pro ekonomickou spolupráci a rozvoj (OECD).

8 Význam slovního spojení směřuje právě k ochraně životního prostředí. Ekvivalent by mohl být „veřejné zadávání šetrné k životnímu prostředi““ nebo „veřejné zadávání odpovědné k životnímu prostředí.“

9 Upřednostňuje se plnění šetrné k životnímu prostředí.

10 Viz ENVIRONMENT POLICY COMMITTEE. Improving the Environmental Performance of Public Procurement: Report on Implementation of the Council Recommendation [online]. 2007 [cit. 2018-06-01]. Dostupné z: http://webdomino1.oecd.org/horizontal/oecdacts.nsf/linkto/C(2002)3.

11 COMMISSION OF THE EUROPEAN COMMUNITIES. Green paper in integrated product policy. In: Europa.eu [online]. Brusel, 2001 [cit. 2018-06-01]. Dostupné z: http://ec.europa.eu/environment/ipp/2001developments.htm

12 Integrovaná produktová/výrobková politika.

13 Viz $§ 114$ odst. 2 ZZVZ a podrobněji potom $\S 117$ a $118 \mathrm{ZZVZ.}$

14 Nelze si nevšimnout všudypř́tomné výzvy omezení nadužívání plastových obalů a jednorázových výrobků z plastu a jeho nahrazování př́rodními nebo ekologicky šetrnými výrobky. 
výhody jen zadavateli samému, ale též celé společnosti a ekonomice státu, a současně minimalizuje škody na trhu a životním prostředí. ${ }^{15}$ Jedná se o komplex hodnot, které ve svém souladu vytváŕí dlouhodobou udržitelnost.

Udržitelné zadávání nepředstavuje jedinečnou nebo jednotnou konstantu, která by měla být pro všechny zadavatele stejná. Udržitelné zadávání bude $\mathrm{v}$ každém státu odpovídat jiným hodnotám, protože vyjadřuje určitou politiku státu, jež je prostřednictvím udržitelného zadávání aplikována do praxe. Pro dosažení požadované efektivity má na udržitelné zadávání vliv množství zadavatelů, kteří se k systému přihlásí a objem jimi zadaných veřejných zakázek.

V praxi často slyšíme, že udržitelné zadávání nebo jakékoliv jiné odpovědné zadávání činí pořizované plnění dražším. Dokonce se lze setkat s tím, že zadavatelé se brání implementovat odpovědné zadávání jen proto, že považují právní předpisy za překážky možnosti aplikovat odpovědné zadávání. V rámci otevřených soutěží mají za to, že by omezující požadavky, které k naplnění myšlenky odpovědného zadávání vedou, měly negativní vliv na soutěž samou. ${ }^{16}$

Na prvním místě vytváří vhodné podmínky pro aplikaci specifické formy zadávání veřejné zakázky dotčený právní předpis. Dále je vhodná aktivní a transparentní podpora vlády, která jasně deklaruje, že upřednostňuje odpovědné zadávání a vyzývá k němu zadavatele. Taková podpora musí být intenzivní a aktivní tak, aby jasně vláda vyjádřila, že se jedná o jí podporovanou politiku, jejímž nástrojem se stává veřejné zadávání. Je pak na zadavatelích, tj. vedoucích organizačních složek, orgánů a dalších subjektů povinných zadávat veřejné zakázky, kteří musí rovněž podporovat odpovědné zadávání v rámci jimi řízených organizací a aplikovat jej na vybrané druhy zboží, služeb nebo stavebních prací. A konečně třetím aspektem je hodnota plnění pořízeného $\mathrm{v}$ rámci odpovědného zadávání. Takové plnění získané formou odpovědného zadání veřejné zakázky nesmí překračovat hodnotou princip „value for the money". ${ }^{17}$

Udržitelné zadávání se stalo předmětem i mezinárodní normy ISO ${ }^{18}$ Pod označením ISO 20400 Sustainable Procurement se skrývá norma, jejímž obsahem jsou standardy pro udržitelné nakupování. Norma vychází z předpokladu, že řada subjekti̊ si stanoví environmentální, sociální a další cíle a tyto pak realizuje mimo jiné i prostřednictvím svých nákupů. Podle normy se subjekty musí chovat dlouhodobě, nelze normu aplikovat jen částečně a po omezenou dobu. Organizace, která vlastní certifikát ISO 20400 musí implementovat procesní modely a rozvíjet svoji činnost v oblasti udržitelného zadávání.

Odpovědné veřejné zadávání může a také většinou i působí jako program k naplňování vybraných politik státu v oblastech, které si programově určí. Potenciál oblasti veřejného zadávání je přitom obrovský. Jednak je třeba si připomenout, že např. v České republice prostřednictvím veřejných zakázek vynaložíme více než 500 miliard korun ročně. A nezanedbatelně působí i chování veřejných zadavatelů, jež může potenciálně ovlivnit i chování běžných spotřebitelů. Prostřednictvím odpovědného veřejného zadávání lze působit i na regionální problémy. Př́kladem může být zaměstnávání osob, které v určitém regionu vykazují nízkou zaměstnanost. Nebo podpora vybraných segmentů trhu.

15 Department for Enviromental, Food and Rural Affairs. Procuring the Future: Sustainable Procurement National Action Plan: Recommendations from the Sustainable Procurement Task Force. Londýn: Department for Enviromental, Food and Rural Affairs, 2006.

16 BRAMMER, Stephen a Helen WALKER. Sustainable procurement in the public sector: an international comparative study. 2011, 31(4), 452-476. DOI: 10.1108/01443571111119551. ISSN 0144-3577. Dostupné také z: https://www.emeraldinsight.com/doi/10.1108/01443571111119551.

17 Princip založen na optimální kombinaci nákladů a kvality.

18 ISO představuje zkratku pro Mezinárodní organizaci pro normalizaci (International Organization for Standardization). 
Způsobilost zadavatelů, vyjádřena objemem vynaložených prostředků, zajištuje základní předpoklad úspěchu a řádné implementace odpovědného veřejného zadávání. Množství zapojených zadavatelů v systému a zejména jejich prostřednictvím vynaložené finanční prostředky ve prospěch společného odpovědného cíle, může znamenat zásadní změnu $\mathrm{v}$ chování. A to jak dodavatelů, tak i odběratelů. Lze tak formovat trh v duchu moderních, resp. společensky odpovědných trendů.

Protikladem je názor Marrona ${ }^{19}$, který s výše uvedeným polemizuje. Nepovažuje instrument odpovědného veřejného zadávání za dostatečně efektivní. Ke stejnému závěru došel i Lundberg, který Marronovu práci aktualizoval a navázal na jeho dř́vější závěry. ${ }^{20}$ Přitom oba zejména okazují na nízkou efektivitu, jíž je prostřednictvím odpovědného zadávání dosahováno. Shledávají ji v oblasti pořizovaného plnění. Také však v oblasti dotčeného zájmu, který je formou odpovědného zadávání podporován.

Jak již bylo zmíněno, vhodné právní předpoklady pro aplikaci odpovědného veřejného zadávání obsahuje platná evropská zadávací směrnice. Mezi strategické cíle určené směrnicí totiž patří i podpora malých a středních podniků a zohledňování sociálních a environmentálních aspektů veřejného zadávání. Malé a střední podniky nejčastěji působí jen v omezeném regionu, což je zpravidla místo jejich sídla. Podpora těchto podniků směřuje do jejich teritoriálně omezeného domicilu.

Zákon o zadávání veřejných zakázek, resp. zákon o verejnom obstarávaní, jež představuje transpozici evropské zadávací směrnice do vnitrostátního právního řádu, je pro odpovědné veřejné zadávání prripraven. Naráží na typické konzervativní chování zadavatelů. Pro ně je typické, že z různých důvodů stále upřednostňují jediné kritérium výběru, a to je nejnižší nabídková cena. Lze jim rozumět, nebot' obstát s vysvětlením stanovení odlišných kritérií hodnocení u řady auditních orgánů, nebývá jednoduché. Jak zdůvodnit, že zadavatel nevybírá obecné zboží podle ceny, ale zohledňuje i kvalitu? Např́íklad u textilu, kancelářských potřeb nebo drogistického zboží? Přitom řešením by byl např. veřejný závazek k odpovědnému chování př́i pořizování zboží a služeb. Řada zadavatelů se k odpovědnému zadávání přihlásila a typicky pilotně zavádí postupně do praxe svůj veřejně deklarovaný záměr odpovědného zadávání.

Zohledňování určitých aspektů, které ve svém komplexu tvoří odpovědné veřejné zadávání, není v rozporu s platným právním řádem. Vycházeje přitom z aktuální zadávací směrnice, která ve své preambuli odkazuje na strategii „Evropa 2020. Strategie pro inteligentní a udržitelný růst podporující začlenění.“21 Přitom připomíná, že směrnice musí umožnit zadavatelům vhodně využívat veřejné zakázky pro podporu společenských cílů. Díky tomuto odkazu lze podpořit zadavatele, aby stanovil jako podmínky účasti v zadávacím řízení např́klad i takové podmínky plnění, které se uplatní v oblasti vlivu předmětu zakázky na životní prostředí, sociální důsledky nebo oblasti hospodářství a inovací. ${ }^{22}$ Český, jakož i slovenský zakázkový zákon se díky tomu vymezil co do dotčených oblastí odpovědného veřejného zadávání. Zadavatel má v zákoně oporu při hodnocení zohledňující zmiňovaný životní cyklus plnění. Kromě toho může zadavatel hodnotit kvalitu nabízeného plnění podle kritérií, která vyjadřují environmentální nebo sociální hlediska spojená s předmětem veřejné zakázky. ${ }^{23}$

19 MARRON, D. B. (1997). Buying green: Government procurement as an instrument of environmental policy. Public Finance Review, 25(3), 285-305.

20 LUNDBERG, S., MARKLUND, P.-O., \& STRO“MBA“CK, E. (2016). Is environmental policy by public procurement effective? Public Finance Review, 44(4), 478-499.

21 Dostupná zde: https://www.mmr.cz/getmedia/7c31b211-1a5a-46a8-b6bd-151b72dc94ec/EU2020-CJ.pdf.

22 Viz $§ 37$ zákona o zadávání veřejných zakázek.

23 § 116 zákona o zadávání veřejných zakázek a $\$ 44$ odst. 3 zákona o verejnom obstarávaní. 
Odpovědné veřejné zadávání je předně instrumentem veřejné politiky. Jako takové musí naplňovat tři předpoklady, aby je bylo lze považovat za funkční. Prvně musí být instrument efektivní, dále počet instrumentů musí odpovídat i počtu odpovědných cílů a také je třeba zajistit vzájemnou nezávislost cílů a instrumentů. ${ }^{24}$

Každý nástroj veřejné politiky bude efektivní pouze za předpokladu, že je vytvořen a implementován tak, aby mohl působit zamýšlené důsledky, tedy vliv na vytyčenou oblast. Efektivitu veřejného zadávání jako nástroje veřejné politiky lze ilustrovat na př́kladu ze Švédska. Tato země si vytyčila jako jeden z cílů odpovědné veřejné politiky zvýšení konzumace organických potravin. K tomu mělo přispět rozhodnutí parlamentu v roce 2006 certifikovat nejméně $20 \%$ zemědělské půdy jako organické do konce roku $2010{ }^{25}$ Tato strategie byla později dokonce rozšířena o střednědobý plán do roku 2030, jež rovněž zahrnoval konzumaci organických potravin a certifikaci zemědělské půdy. Zadavatelé v prrípadě pořizování potravin nebo jejich složek zajišt'ovaly naplňování těchto cílů tak, že hodnotili nabízené produkty s ohledem na jejich původ, resp. kvalitu. Současně se stal relevantním požadavek na kvalitu nabízeného plnění v rámci technické kvalifikace. Z hlediska efektivity lze jistě polemizovat o tom, že zvýšení množství certifikované půdy lze zajistit i jiným, vhodnějším nástrojem. ${ }^{26}$ Pak by se jako vedlejší efekt dostavil i druhý cíl, tedy zvýšená konzumace organických potravin. Byl by ovšem závislý na efektivitě prvního nástroje. Př́mé pořizování organických potravin pak může být $\mathrm{k}$ dosažení takového cíle efektivnějším nástrojem, kdy jejich vzájemná interakce není podmíněná.

Z hlediska veřejného zadávání není odpovědné zadávání integrální součástí hlavního cíle. Jím je uspokojení potřeby zadavatele. Základní potřeba by měla být jednoduše definovaná a tedy i nezávislá na dosahování efektivní odpovědné politiky státu. Veřejné zadávání je sice jedním z nástrojů, jimiž lze dosahovat odpovědných veřejných cílů, ale nemělo by se stát tím jediným nástrojem. Pak vlastně nelze dosáhnout ničeho. Ani uspokojení potřeby zadavatele, ani působení na trh požadovaným způsobem. ${ }^{27}$

Možnosti odpovědného zadávání veřejných zakázek vychází ze zadávací směrnice a tato je strategicky označuje za primární cíle veřejného zadávání. Nelze tedy hledět při kladení důrazu na environmentální, sociální a další hlediska při zadávání veřejných zakázek jako na zvláštní kategorii veřejných zakázek, která by podléhala specifickým principům. Zcela v opačném měřítku je nutné hledět na udržitelné zadávání jako na standardní způsob zadávání veřejné zakázky. Významně klade důraz na princip value for money, který právě zohledňuje vše, co může zadavatel získat, aniž by bylo nutné poměřovat pouze hodnotu plnění. V odpovědném veřejném zadávání má místo princip odpovědnosti, jež sice není obecně přítomen veřejnému zadávání, ale právě pro to udržitelné je aplikovatelný. Klade důraz na odpovědností stránku plnění, kterou zadavatel zohledňuje při plnění svých vlastních úkolů nebo předem stanovených strategických cílů souvisejících s udržitelností. Ta, aby se nestala prázdnou proklamací, musí být aplikovatelná při všech činnostech, tedy i nákupu zboží, služeb a stavebních prací.

24 Mundell, R. A. (1968). The nature of policy choices. In Mundell R. A. (Eds.), International Economics, ch 14. London: MacMillan.

25 Government Communication (2006). Ekologisk produktion och konsumtion - Ma ${ }^{\circ} 1$ och inriktning till 2010. Regeringens skrivelse Skr. 2005/06:88.

26 Lze uvažovat o veřejné podpoře, cílené dotační politice, daňových úlevách apod.

27 LUNDBERG, Sofia a Per Olov MARKLUND. Green public procurement and multiple enviromental objectives. Economia e Politica Industriale Economia e Politica Industriale. Springer International Publishing, 2018, 45(1), 37-53. DOI: https://doi.org/10.1007/s40812-017-0085-6. ISSN 1972-4977. 


\section{PŘÍKLADY DOBRÉ PRAXE}

Sociálně odpovědné zadávání se často pojí se zaměstnáváním určité skupiny lidí, které jsou na trhu znevýhodněny. Promyšlenou strategii implementovalo např́klad Město Kadaň pro začleňování osob nezaměstnaných pro plnění veřejných zakázek. V rámci interní legislativy stanovilo následující podmínku:

„Do zadávaci dokumentace na stavebni práce bude doplněna zvláštní podmínka naplnění veřejné zakázky: „zadavatel požaduje, aby alespoň $10 \%$ zcelkového počtu pracovníkù dodavatele, minimálně jeden, kteři se budou podílet na plnění zakázky, přijme dodavatel dopracovního poměru či snimi uzavre dohodu o pracích konaných mimo pracovní poměr. Jedná se o pracovniky zřad sociální oblasti aoblasti zaměstnanosti, např. absolventy škol." (podmínky budou upřesněny vzadávaci dokumentaci). Zvláštní podmínka se považuje za splněnou, vpř́padě predložení potvrzení o tom, že $v$ evidenci uchazeču se nenachází požadované profese kontaktním pracovištěm úŕadu práce Kadaň.“"28

Město tak zohledňuje zaměstnávání osob nezaměstnaných, profilujících se z řad určitých skupin (typicky absolventi škol) a současně je tento aspekt zaměřen na konkrétní místo (srovnej povinnost předložit potvrzení vydané pracovištěm úřadu práce $\mathrm{v}$ Kadani), čímž podporuje pouze teritoriálně omezené území.

Pro sociálně odpovědné zadávání se typicky zohledňuje podíl osob se zdravotním postižením, které se na plnění veřejné zakázky podílí. Podporují se v určitých oborech firmy zaměstnávající tyto osoby (často služby ostrahy, tiskařské služby apod.). V praxi nastává problém, kdy sice papírově firmy určitý počet pracovníků se zdravotním postižením vykazují, ale fakticky je k plnění nevyužívají. Tento aspekt musí zadavatel předvídat a vytvářet podmínky pro vyloučení takového nekalého jednání. Vhodně to lze učinit ve smlouvě, kterou jako výsledek zadávacího řízení uzavře a pod sankcí si vymíní určitý počet specifických osob, které budou plnění fakticky vykonávat a možnost kontroly plnění takové podmínky.

Trendem udržitelného zadávání je zohledňování specifických aspektů. Např́ílad při nákupu textilu zadavatel bude zadavatel podmiňovat nabízené plnění tím, že musí využívat čistě př́rodních materiálů, nepodílí se na jeho výrobě děti nebo osoby k práci nucené apod. Tato kritéria si zadavatel může ověřit certifikací výrobků nebo čestným prohlášením vydaným zadavatelem. Obdobně může ověřovat tytéž aspektu při pořizování např́íklad potravin nebo obecně dodávání hotových jídel, kde bude požadovat jasný původ použitých potravin s důrazem na ekologický způsob pěstování nebo chovu, vyloučení dětské a nucené práce nebo vyloučení používání chemicky modifikovaných potravin. Není ničím výjimečným, že výrobky dnes získávají obecná označení kvality, procesů výroby apod., která jsou udělována na základě obecně definovaných pravidel. Zadavatelé se tak mohou opírat o vystavené certifikáty a značky, což ověřuje splnění jimi stanovených podmínek plnění. Dalším příkladem je pak využití ekologicky šetrných prostředků při poskytování služeb spočívajících v úklidu. ${ }^{29}$

Zadavatelé dnes již vcelku standardně vybavují kanceláře nábytkem vyrobeným z ekologických materiálů. Takový nábytek nejenže nezatěžuje životní prostředí při vlastní likvidaci, ale současně neohrožuje zdraví lidí tím, že produkuje škodlivé výpary apod. Neméně závažným problémem jsou obalové materiály, kdy požadavek na ně může být zrovna oním prvním implementačním krokem organizace hlásící se k zavedení odpovědného

28 Viz Pravidla pro zadávání veřejných zakázek malého rozsahu městem Kadaň, dostupná zde: http://www.mestokadan.cz/dokumenty/dotace/PravidlaVZmale2016.pdf

29 Např. veřejná zakázka „Zajištění ekologického úklidu v objektu MPSV“ vyhlášená Ministerstvem práce a sociálních věcí 2. 9. 2014, dostupná zde: https://mpsv.ezak.cz/contract_display_28.html 
zadávání. Navíc se jedná o takovou součást všech dodávaných produktů, kterou mohou využít u většiny poptávaného plnění.

\section{ZÁVĚR}

Odpovědné veřejné zadávání má řadu forem. Není pro podstatu toho, co zosobňuje, relevantní, jak jej přesně označujeme. Význam odpovědného zadávání spočívá v jeho praktických dopadech na dotčené oblasti zájmu. Pozitivně může stát prostřednictvím odpovědného zadávání realizovat vlastní politiku, jež spočívá v podpoře určitých skupin obyvatelstva, regionů, výrobků, výroby nebo segmentu podnikání obecně.

Velká řada veřejných zakázek může být zadávána takovým způsobem, aby zadavatelé vyjadřovali svůj pozitivní postoj k životnímu prostředí. Nemusí se přitom jednat o nijak propracovaný systém veřejného zadávání, ale postačí plošné zavedení podmínky zohledňující například ekologicky šetrné obalové materiály a jejich ekologickou likvidaci.

Zadavatelé př̀i uskutečňování odpovědného zadávání vytváří vhodné nástroje $\mathrm{k}$ tomu, aby byla jejich prostřednictvím naplňována strategie státu, jakož i působí na obyvatele, jimž jde př́íkladem. Existuje zejména v oblasti ochrany životního prostředí a zajištění udržitelnosti mnoho jednoduchých a snadno uskutečnitelných kroků, které může činit každý jednotlivec.

Ačkoliv se může zdát, že odpovědné zadávání je jen trendem doby, opak je pravdou. Ochrana životního prostředí a schopnost chovat se odpovědně v horizontu řady let do budoucna, by neměla být moderní a trendová. Měla by se stát součástí současné společnosti vyjadřující odpovědnost vůči mladé generaci a neochotu podporovat to, co považujeme za odsouzeníhodné nebo snad dokonce v rozporu se základními lidskými právy.

\section{KLÍČOVÁ SLOVA}

Veřejné zadávání, odpovědné veřejné zadávání, udržitelné veřejné zadávání,

\section{KEY WORDS}

Public procurement, responsible public procurement, sustainable public procurement

\section{POUŽITÁ LITERATURA}

1. BRAMMER, Stephen a Helen WALKER. Sustainable procurement in the public sector: an international comparative study. 2011, 31(4), 452-476. DOI: 10.1108/01443571111119551. ISSN 0144-3577. Dostupné také z: https://www.emeraldinsight.com/doi/10.1108/01443571111119551

2. COMMISSION OF THE EUROPEAN COMMUNITIES. Green paper in integrated product policy. In: Europa.eu [online]. Brusel, 2001 [cit. 2018-06-01]. Dostupné z: $\mathrm{http} / / / \mathrm{ec}$.europa.eu/environment/ipp/2001developments.htm

3. Department for Enviromental, Food and Rural Affairs. Procuring the Future: Sustainable Procurement National Action Plan: Recommendations from the Sustainable Procurement Task Force. Londýn: Department for Enviromental, Food and Rural Affairs, 2006.

4. ENVIRONMENT POLICY COMMITTEE. Improving the Environmental Performance of Public Procurement: Report on Implementation of the Council Recommendation [online]. 2007 [cit. 2018-06-01]. Dostupné z: http://webdomino1.oecd.org/horizontal/oecdacts.nsf/linkto/C(2002)3.

5. Government Communication (2006). Ekologisk produktion och konsumtion - $\mathrm{Ma}^{\circ} 1$ och inriktning till 2010. Regeringens skrivelse Skr. 2005/06:88. 
6. LI, Lin a Ken GEISER. Environmentally responsible public procurement (ERPP) and its implications for integrated product policy (IPP). Journal of Cleaner Production. 2005, 7(13), 10. ISSN 0959-6526. Dostupné na : https://doi.org/10.1016/j.jclepro.2004.01.007

7. LUNDBERG, Sofia, MARKLUND, P.-O., \& Stro“mba”ck, E. (2016). Is environmental policy by public procurement effective? Public Finance Review, 44(4), 478-499. Dostupné na : https://doi.org/10.1177/1091142115588977

8. LUNDBERG, Sofia a Per Olov MARKLUND. Green public procurement and multiple enviromental objectives. Economia e Politica Industriale Economia e Politica Industriale. Springer International Publishing, 2018, 45 (1), 37-53. Dostupné na https://doi.org/10.1007/s40812-017-0085-6. ISSN 1972-4977.

9. MARRON, D. B. (1997). Buying green: Government procurement as an instrument of environmental policy. Public Finance Review, 25(3), 285-305. Dostupné na https://doi.org/10.1177/109114219702500302

10. MUNDELL, R. A. (1968). The nature of policy choices. In Mundell R. A. (Eds.), International Economics, ch 14. London: MacMillan.

11. Nařízení Evropského parlamentu a Rady (ES) č. 2195/2002 ze dne 5. listopadu 2002 o společném slovníku pro veřejné zakázky (CPV)

12. NOVÁK, David, Leona GERGELOVÁ ŠTEIGROVÁ, Monika DOBROVODSKÁ, et al. Odpovédné veřejné zadáváni: metodika. Praha: Ministerstvo práce a sociálních věcí ČR, 2017. ISBN 978-80-7421-134-8. str. 6.

13. Pravidla pro zadávání veřejných zakázek malého rozsahu městem Kadaň, dostupná zde: http://www.mesto-kadan.cz/dokumenty/dotace/PravidlaVZmale2016.pdf

14. Směrnice Rady 71/305 EHS ze dne 26. července 1971 o koordinaci postupů zadávání veřejných zakázek na stavební práce a směrnice Rady 77/62/EHS ze dne 21. prosince 1976 o koordinaci postupů zadávání veřejných zakázek na dodávky

15. Směrnice 93/36/EHS o koordinaci postupů při zadávání veřejných zakázek na dodávky, 93/37/EHS o koordinaci postupů při zadávání veřejných zakázek na stavební práce a 92/50 o koordinaci postupů při zadávání veřejných zakázek na služby

16. Směrnice Evropského parlamentu a Rady 2014/24/EU ze dne 26. února 2014 o zadávání veřejných zakázek a o zrušení směrnice 2004/18/ES

17. Směrnice č. 2004/18/ES o koordinaci postupů při zadávání veřejných zakázek na stavební práce, dodávky a služby

18. Zákon č. 134/2016 Sb., o zadávání veřejných zakázek

19. Zákon č. 343/2015 Z.z., o verejnom obstarávaní

\section{KONTAKTNÍ ÚDAJE}

\section{JUDr. Kateřina Burešová}

Západočeská univerzita v Plzni,

Fakulta právnická

Doktorandka Katedry obchodního práva

e-mail: kburesov@fpr.zcu.cz 